\title{
Challenges for conserving biodiversity and developing sustainable island tourism in North Sulawesi Province, Indonesia
}

\author{
Luchman Hakim $^{1,2}$, Marno Soemarno ${ }^{2}$ and Sun-Kee Hong ${ }^{3, *}$ \\ ${ }^{1}$ Department of Biology, Faculty of Mathematics and Natural Sciences, Brawijaya University, Malang 65145, East Java, Indonesia \\ ${ }^{2}$ Graduate School of Environment and Development Studies, Brawijaya University, Malang 65145, East Java, Indonesia \\ ${ }^{3}$ Institution for Marine and Island Cultures (MIC), Mokpo National University, Muan 534-729, Korea
}

\begin{abstract}
Recent conditions in North Sulawesi Province (NSP) have become favorable for the development of tourism. In this paper, we present the recent status of biodiversity and tourism in NSP as a basic consideration towards integrative biodiversity conservation strategy. Overall, biological accounts suggest that NSP is important for the world biodiversity conservation program. NSP's biodiversity makes the area a major nature-based tourism (ecotourism) site in the world. Development of diverse tourism programs in NSP has provided new opportunities for balancing development and conservation of regional ecosystems. However, the excessive tourism growth in some particular areas in NSP has been identified as the primary factor of environmental degradation. Nowadays, biodiversity of North Sulawesi regions are suffering from the number of tourist impacts and facilities. Based on those conditions, tourism planning and development in NSP is needed to formulate a proper strategy to protect the ecosystem and biodiversity from degradation and extinction. This will be a new challenge of sustainable island tourism development and biodiversity conservation in NSP.
\end{abstract}

Key words: biodiversity conservation, island development, North Sulawesi Province, sustainable tourism

\section{INTRODUCTION}

The term biodiversity refers to the variability of lives on earth. Biodiversity comprises all the natural resources that provide useful goods and services for mankind. While biodiversity has a number of important functions, recently, many of them have been heavily threatened due to human activities (Naumann 2001). Large-scale deforestation in many developing countries has significantly decreased the degree of biodiversity. According to Rhee et al. (2004), illegal logging and harvesting are also recognized as significant factors to rapid biodiversity extinction. Moreover, poor natural resources management and practices are continuing to decrease biodiversity in many developing countries (Fox et al. 2000, Kartodihardjo and Supriono 2000). Loss of biodiversity means loss of re- sources and ecosystem services and therefore threats human sustainability in the biosphere (Cunningham et al. 2003, Rhee et al. 2004).

The Indonesian tropical rain forest exhibits a high degree of biodiversity. The total number of known higher plant species is over 23,975 species. The number of mammal species is known be about 515 species. There are 929 known species of birds from the Indonesian archipelago. A total of 745 reptile species and 278 amphibian species are known from Indonesia. Fish comprises approximately 4,080 species from marine and freshwater ecosystems (BAPPENAS 2003). Many of them are endemic to Indonesia. Unfortunately, the rate of degradation has increased dramatically (Hakim and Nakagoshi 2008). The forces

\section{Open Access http://dx.doi.org/10.5141/JEFB.2012.017}

This is an Open Access article distributed under the terms of the Creative Commons Attribution Non-Commercial License (http://creativecommons org/licenses/by-nc/3.0/) which permits unrestricted non-commercial use, distribution, and reproduction in any medium, provided the original work is properly cited. pISSN: 1975-020X eISSN: 2093-4521
Received 02 April 2012, Accepted 09 April 2012

*Corresponding Author

E-mail: landskhong@gmail.com

Tel: +82-61-450-6272 
leading to deforestation vary from place to place within Indonesian islands. However, it is clear that logging and forest conversion of tropical rain forests have caused a rapid decrease in the forest cover in Indonesia (Kartodihardjo and Supriono 2000, BAPPENAS 2003, Rhee et al. 2004).

It is generally assumed that forest degradation is related to poverty. Many communities in poor areas depend on illegal hunting for food. Poor people cut trees for sale in illegal markets. Moreover, absence of scenario for sustainable use of biodiversity also becomes the crucial factor that leads to deforestation. According to scholars, deforestation and biodiversity decrease will not improve unless the basic economic needs are improved (Roe et al. 2003, Kumar 2010). Consequently, developing effective strategies to provide jobs and increasing economic benefits for local people will bring about positive changes to biodiversity conservation. Hence, ecotourism has been proposed as an important strategy. Ecotourism has been recognized to have a significant contribution to the development of local economy (Damanik et al. 2005, Drumm and Moore 2005). Ecotourism is a form of sustainable tourism and can be particularly appropriate for developing countries. The benefits of ecotourism within the idea of biodiversity conservation are gradually being acknowledged and identified. For many tourism destinations, tourism supports the local economic development, promotion of local culture, education, and the quality of life of local people. As a sustainable business, ecotourism is a promising alternative to local and national development as well as being a clean and environmentally friendly business. Thus, ecotourism is probably the most effective strategy for many developing countries (Kinnaird and O'Brien 1996, Ross and Wall 1999, Gunn and Var 2002, Hakim et al. 2008, 2009, Hong 2011).

In the context of Indonesia, ecotourism has been studied extensively because of its economic benefits and contributions to local development. In the case of Indonesia, the main challenge is not only related to the country's natural capital richness, but also global tourist visitation trends (Damanik et al. 2005, Hakim and Nakagoshi 2008, Hakim 2011). In the first semester of 2010, Asia was the most visited region in the world. At the same time, international tourist arrival to Bali, the main tourism destination in Indonesia, increased by $9 \%$. Tourism to natural environments has been growing significantly. Although a number of tourism studies have been implemented, a comprehensive study related to the importance of biodiversity, tourism planning and development has not been carried out. Over time, an increasing number of tourists will be a threat to biodiversity. Recent discussions about biodiversity and tourism in Indonesia have highlighted the needs for more research and study to understand the links between biodiversity, tourism and sustainability (Hakim et al. 2008).

North Sulawesi Province (NSP) is one of the popular tourism destinations in eastern Indonesia. Tourism has been growing since the 1970's and nowadays its contribution to provincial earnings is considered significant. Recently, favorable conditions for the development of tourism in NSP have been due to the socio-political factors. Local government plays an important role in developing tourism events, establishing new vacation sites and promoting NSP as a new world's tourism destination (Whitten et al. 1987). Biodiversity and environmental factors contribute significantly to the tourism sector. Nevertheless, much of the research carried out on tourism has been focused on the economical aspect and less attention has been paid on the ecological aspect. Very few study of the role of biodiversity on the tourism development has been conducted in South Sulawesi. Therefore, the aims of this paper are to 1) document the recent status of biodiversity, 2) review the recent status of tourism characteristics in NSP, 3) determine the impact of tourism on biodiversity, and 4) discuss the strategy to achieve sustainable tourism development in NSP.

\section{BIODIVERSITY OF NSP}

The NSP located in the northern part of Sulawesi Island, Indonesia, covers an area of approximately $15,273.10 \mathrm{~km}^{2}$. This province consists of the longest and thinnest peninsula in the southern part of Sulawesi Island. Small islands encompass Manado Tua, Bangka, Talise, Bunaken, Mantehage, Lembeh, Siau, Tagulandang, Karakelang, Karabuan, and Salibabu (Fig. 1). This province contains a diverse ecosystem ranging from coastal to mountainous ecosystems. The mean annual temperature is $26^{\circ} \mathrm{C}$ and rain fall ranges from 1,133 $\mathrm{mm}$ to more 1,562 per annum. This province has more than $1,837 \mathrm{~km}$ of coastline that incorporates many diverse types of ecosystems (Whitten et al. 1987, BPS Sulut 2009).

North Sulawesi comprises important regions of tropical rain forest in which biological diversity is extremely high. Various factors such as soil chemistry, soil water, climate, and altitude contribute significantly to diversity and composition of natural vegetation. Nevertheless, the recent continual growth of human population is reported to be the greatest threat to the luxurious forest in NSP. Since 


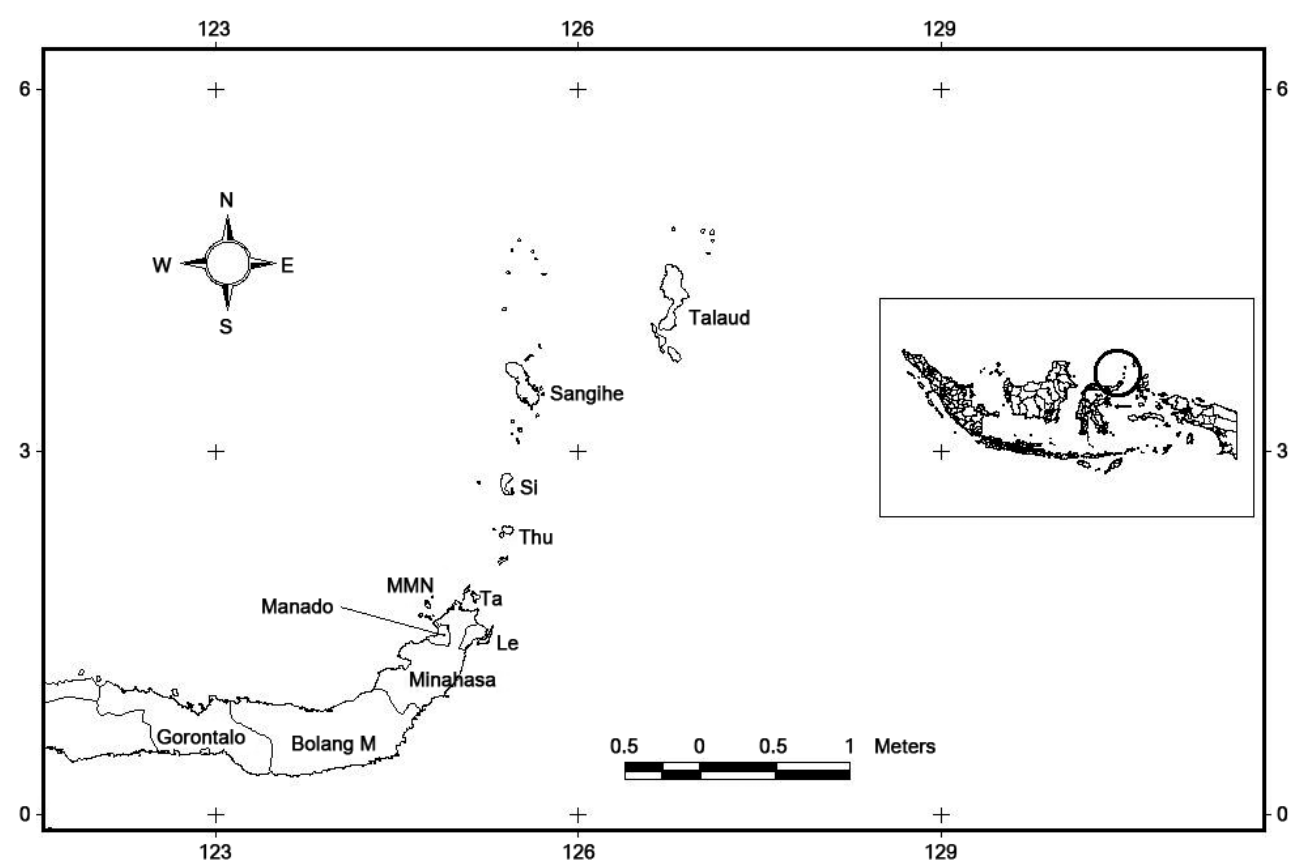

Fig. 1. Geographical location of North Sulawesi Province, Indonesia.

the end of the 1970's, the landscape of north Sulawesi has been transformed through deforestation. In the 1990s, degraded forest in NSP reached 510,384 ha (FWI 1996, Fox et al. 2000). Among the forest types, the highest rate of deforestation occurred in the upper forest (Whitten et al. 1987). The economic crisis at the end of 1997 led to a severe shortage of forest. Timber extraction became one of the main sources of income in the situation of economic crisis (Kartodihardjo and Supriono 2000). Moreover, the massive growth of logging (forest concession rights, Hak Pengusahaan Hutan) and the oil palm industry contributed to the degradation of tropical rain forest. NSP, like many regions in Indonesia and Malaysia, has developed the oil palm industry as a machine of generating incomes. Nowadays, there are 175,958.00 ha of protected forest, $320,543.00$ ha of protected and natural conservation forest, 320,543.99 ha of forest production, and 14,643.00 conversions of forest (BPS Sulut 2009). The current in situ conservation areas in NSP are listed in Table 1.

Biodiversity research on North Sulawesi was begun by A.R. Wallace in 1859, who spent more than four months observing some species of birds and mammals. According to Wallace (2000), tropical forest of North Sulawesi contains high diversity of insects, mammals and birds. The most comprehensive information related to the ecology of Sulawesi was compiled by Whitten et al. (1987). Additional information related to the biodiversity of Sulawesi is provided in several reports by Indonesian Institute of Science (LIPI), Department of Forestry, Birdlife International, World Wide Fund for Nature (WWF), and other conservation bodies. Indonesia government, Non-governmental Organization (NGO) and conservation agency realized that NSP is a crucial place for the world's biodiversity conservation (BAPPENAS 2003). Efforts to complete the biodiversity status of North Sulawesi principally show that it is a critical habitat of biodiversity in the world.

The historical roots of species diversity and endemism in North Sulawesi can be traced to the process of island establishment in the late Pliocene (3 Ma ago). Because of the long history of geological processes, Sulawesi has

Table 1. Conservation area in North Sulawesi Province

\begin{tabular}{llc}
\hline Categories & \multicolumn{1}{c}{ Name } & Area (Ha) \\
\hline National Park & Bunaken $^{*}$ & 89,065 \\
& Bogani Nani Wartabone $^{\dagger}$ & 287,155 \\
Nature Reserve & Mt. Ambang & 8,638 \\
(Cagar Alam) & Mt. Dua Saudara & 4,299 \\
Wildlife Reserve & Nantu & 31,215 \\
(Suaka Margasatwa) & Mt. Manembo-Nembo & 6,500 \\
\hline
\end{tabular}

Source: Indonesia Law No. 26 Year 2008, March 10, 2008 (Government of Indonesia 2008).

"Marine National Park.

${ }^{\dagger}$ Share with Gorontalo Province. 
come to possess diverse and unique flora and fauna. This high diversity encompasses a large number of endemic and rare species (Whitten et al. 1987). While biodiversity information of Sulawesi Island is relatively completed, little is known in detail about the number of plants, reptiles and amphibians in NSP (Table 2).

The most famous animals are the Babyrusa (Babyrousa babyrussa), Anoa (Bubalus depressiocornis and Bubalus quarlesi), Cuscus (Ailurops ursinus and Stringocuscus celebensis) and Tarsier (Tarsius spectrum). North Sulawesi is also the home of endemic macaques, including Blackcrested macaque Macaca nigra and M. nigrescens. Twenty bat species were reported endemic including Sulawesi fruit bat Acerodon celebensis and Talaud fruit bat Acerodon humilis (Kinnaird 1997, Teguh et al. 2001, Ramadhanil and Gradstein 2004). Most of them have been listed as Endangered species by International Union for Conservation of Nature (IUCN) and categorized into CITES Appendix I and II. This status presents significant information that these species are more at risk of extinction.

Sulawesi is home to about 332 species of birds. Among the bird species living in NSP, Maleos (Macrocephalon maleo) are probably the most famous birds (Whitten et al. 1987, Holmes 1996). In the same field, Kinnaird (1997) reported that the actual number of birds species present in North Sulawesi may be 280 species. It is very interesting that new species of birds continue to be found in NSP. Since 1995, four new bird species have been discovered in North Sulawesi and three of those were found in remote areas in Sangihe-Talaud Islands. Moreover, Rasmussen (1999) found a new species of Hawk-owl Ninox ios from Bogani Nani Wartabone forest at 1,120 m. However, their population distribution and conservation status are unknown. Diversity and taxonomic status of birds in North Sulawesi are still in its early stages and therefore require intensive collection and study. These works will be sig-

Table 2. Number of identified and endemics species in Sulawesi and North Sulawesi Province (NSP)

\begin{tabular}{lcccccc}
\hline & \multicolumn{2}{c}{$\begin{array}{c}\text { Sulawesi and its } \\
\text { adjacent islands }\end{array}$} & & \multicolumn{2}{c}{ NSP } \\
\cline { 2 - 3 } \cline { 5 - 6 } Taxon & $\begin{array}{c}\text { Identified } \\
\text { species }\end{array}$ & $\begin{array}{c}\text { Endemic } \\
\text { species }\end{array}$ & & $\begin{array}{c}\text { Identified } \\
\text { species }\end{array}$ & $\begin{array}{c}\text { Endemic } \\
\text { species }\end{array}$ \\
\hline Spermatophytes & 10,000 & 1,500 & & n.a & n.a \\
Aves & 647 & 262 & & 257 & 89 \\
Mammals & 222 & 127 & & 54 & 30 \\
Reptiles & 222 & 99 & & $24^{*}$ & n.a \\
Amphibians & 48 & 33 & & $3^{*}$ & n.a \\
\hline
\end{tabular}

n.a, data not available.

'Identified from Salibabu-Talaud Island (Koch et al. 2009). nificant in that it will create a sound basis for the avifauna conservation.

Discovery of new species has been continuously reported from NSP. The most spectacular discovery was the living Coelacanths, Latimeria chalumnae in 1998 (Erdmann et al. 1999). Coelacanth was previously believed to have gone extinct for over 65 million years until the living species was discovered in the nineteenth century in South Africa and North Sulawesi. Additionally, some small mammals have recently been discovered. For instance, Shekellee et al. (2008) reported of a new species of Tarsier species from the tiny island of Siou. Recent survey by Koch et al. 2009 found 37 specimens of Anuran and Reptiles from Salibabu Island, Talaud, which have never been reported before. These findings point out that NSP is indeed one of the important regions for wildlife conservation in the world.

NSP has a large number of active volcanoes such as Mt. Ambang (1,689 m), Mt. Soputan (1,783.7 m), Mt. Karangetang (1,827 m), Mt. Ruang (714 m), Mt. Submarine (1,922 m), Mt. Awu (1,340 m), Mt. Lokon (1,580 m), Mt. Mahawu $(1,331 \mathrm{~m})$ and Mt. Tangkoko (1,149 m). Mountains provide critical habitats for animals and plant species. For instance, Mt. Tangkoko is the home of endemic species such as crested black macaques Macaca nigra, spectral tarsier Tarsius tarsier and Red-knobbed Hornbill Aceros cassidix (Whitten et al. 1987, Kinnaird 1997, BPS Sulut 2009). The composition and structure of vegetation of mountain regions are relatively unknown, but it was estimated to contain rich biodiversity. The most represented plant species were Ficus sp., Pterocarpus indicus, Palaquium sp., Vitex gopasa, Duabanga moluccana, Amorphophallus plicatus, Phaleria octandra and Talauma candollii. The most important plant was perhaps the endemic orchids Vanda celebica (Whitten et al. 1987, Putri et al. 2006). Further study is needed to determine the plant diversity in the mountain regions. Ultimately, this data can be used to drive the development of management plans in mountain regions. In NSP, study of the mountain areas is principally crucial because mountains are the areas of significant rural and agricultural development (BPS Sulut 2009).

The northern area of NSP consists of 124 islands. The area has an extensive coral reef ecosystem. Bunaken Marine National Park is the most diverse coral reef ecosystem in the world. The park consists of five islands, namely Bunaken, Manado Tua, Mantehage, Naim and Siladen. Invertebrates, especially Cnidarians are abundant in the shallow-waters of North Sulawesi Sea (Ross and Wall 1999, de Vantier and Turak 2004). Approximately 2000 species of fish and 50 genera of coral reefs have been identified 
in Bunaken. Significant marine mammals in the sea water of NSP include Sea cows, Whale and Dolphin (Whitten et al. 1987). This richness of marine creatures has made NSP the Marine Golden Triangle of the world. However, there are still serious problems including illegal harvesting, bombing and tourism activities.

The factors responsible for the decrease in biodiversity include habitat loss, pollution, and illegal logging. Timber extraction was one of the main sources of income. The most commonly extracted species were Dacrydium elatum, Michelia champaca, Shorea sp., Palaquium sp., Pometia pinnata, Heritiera sp., Agathis celebica and Anisoptera sp. Rattans and bamboos have been used as objects of trade. Rattan exploitation increased from 3,255 $\mathrm{m}^{3}$ in 2003 to 3,965 $\mathrm{m}^{3}$ in 2006 (Dishut Sulut 2008). The decrease of rain forest vegetation significantly affects wildlife in NSP. According to Kinnaird and O'Brien 1996, during the period from 1979 to 1994, the rate of wildlife population decline was recorded as $50-95 \%$. The largest species lost were the Anoa Bubalus depressicornis, Bear cuscus Phalanger ursinus, Crested black macaque Macaca nigra, Maleo Macrocephalon maleo and Red junglefowl Gallus gallus. In the last few decades, biodiversity of NSP have suffered greatly and several species have become extinct including Cacatua sulphurea (Teguh et al. 2001). In the middle of the 1980's, a researcher confirmed that there are no records of the endemic Eutrichomyias rowleyi (Whitten et al. 1987). Extensive land use changes, illegal logging and hunting are some of the human pressures that have significantly affected the biodiversity of NSP. Human influence has been recognized as a main factor for environmental degradation and has become the major concern of world discussions. According to scholars, poor socio-economic status in developing countries is one of the significant factors which lead to environmental degradation. Therefore, the main challenge is linking socio-economy improvement agenda into biodiversity conservation scenarios. Several approaches have been introduced and tourism seems to be a successful strategy (World Tourism Organization, World Travel and Tourism Environment Research Center, Earth Council 1996, Ross and Wall 1999, Damanik et al. 2005, Drumm and Moore 2005, Weaver 2005).

\section{Recent status of tourism}

The importance of tourism in NSP is widely acknowledged. Tourism has become one of the most significant sectors contributing to the economic development (Ross and Wall 1999, Walker et al. 2000, Damanik et al. 2005).
This area was toured by those who enjoyed learning directly about the nature and biodiversity of North Sulawesi. The number of international tourists rose from 16,930 visitors in 2004 to 29,715 visitors in 2009. Most of the international tourists visiting North Sulawesi come from Europe (29\%) especially Germany, Netherlands, England, and Italy. Asian tourists (24\%) come from Singapore, Malaysia and the Philippines. Approximately $21 \%$ of East Asian tourists come from Japan, South Korea and Taiwan. A smaller proportion comes from the USA (9\%) and Australia (5\%). There are signs that tourism sectors maybe starting to emerge. According to statistical data, registered local tourist guides increased from 80 people in 2006 to 145 people in 2009. A number of tour and travel businesses increased from 62 in 2006 to 81 companies in 2009. This is followed by the increased number of Taxis which was recorded as 25 units in 2006, but reached 200 units in 2009. Significantly, the number of hotel rooms grew from 1,151 in 2006 to 2,227 units in 2009. These tourism sectors contribute significantly to the NSP's economic development (BPS Sulut 2009).

Since 1980, the provincial government has coordinated an ambitious effort to prepare NSP as one of the world's tourism destination. Parallel to this mission, the opening of new tourism destination began in the 1990's. Within the last two decades, many new tourism facilities and attractions have been flourished in NSP. In 2008, seven fivestar hotels started to build in Manado. Most of them have been set up to meet the international standard. The numbers of tourism destinations have risen from 81 sites in 2001 to 394 sites in 2006. In 2009, there were 545 tourism destinations throughout NSP (Pangemanan et al. 2002, BPS Sulut 2009). This development led to a remarkable era of interest in tourism development in NSP. Nonetheless, the existence of crucial links between tourism, social and environmental attributes are not yet clear.

Principally, nature-based tourism is dominant in NSP. Small islands such as Bunaken, Siladen, Mantehage, and Sangihe-Talaud islands offer spectacular spots to explore marine biodiversity and experience coastal recreation (de Vantier and Turak 2004, Kusen and Tioho 2009). NSP has many lakes, but only few have been promoted as nature based tourism destinations. The most visited lakes were Lake Tondok and Lake Tondano while several lakes such as Linow, Moat, Buyat, Wungangaan and Mokobang were not developed as ultimate tourism destinations (Pangemanan et al. 2002). Lake Tondado in Minahasa Regency is the biggest lake in NSP and has been cited in many tourist brochures and magazines as a prime tourism destination. Nevertheless, poor management of the lakes has been 
causing rapid sedimentation, exotic species invasion and eutrophication. Over the period of 1939-1992, the area of the lakes has decreased from 5,600 ha in 1939 to 4,600 ha in 1992. Sedimentation process has changed the depth of the water from $40 \mathrm{~m}$ in 1934 to $15 \mathrm{~m}$ in 1996 (Sittadewi 2008). Besides Tondano, degradation of natural tourism attractions has occurred significantly in some lakes in NSP.

Coral reef ecosystem is the basis for nature-based tourism in NSP. There are at least 120 dive sites distributed in North Sulawesi. The most number of dive sites are found in Bunaken Island. About 9,000 divers per year come and enjoy NSP's underwater landscape. However, increasing number of divers are influencing to conservation of marine ecosystem. The impact of underwater activities to coral reefs has led to coral disturbance. In Bunaken and adjacent waters, de Vantier and Turak (2004) recorded regarding significant tourist interactions to coral reefs, such as touching, holding, standing on corals, and harassments, which potentially caused coral damage.

In 2000, The North Sulawesi Tourism Promotion Board was established with the mission of developing and promoting NSP as a premier tourism destination. Attempts have taken place to hold international events such as World Ocean Conference (WOC), Coral Triangle Initiative (CTI Summit) and Sail Bunaken in 2009. The notion of tropical marine biodiversity richness has been an important theme used to invite more international tourists. As a result, the impact was significant in economic earnings, but its positive contributions to social and environmental sectors were debatable.

\section{Tourism impact to biodiversity}

Tourism activities are likely to contribute to a series of problems. For instance, tourist facilities contribute to the exploitation of water resources and produce a large amount of waste. Tourism in natural areas can alter vegetation diversity and structure, introduce non-native species, disrupt animal migration, affect wildlife behaviors and population and pollute water resources. NSP has experienced a tremendous tourism growth in the recent decades. Walker et al. (2000) showed that tourism development may have negative consequences not only on biodiversity but also on social, economic, political and cultural aspects. There are mechanisms of tourism impacts on biodiversity which are summarized in Table 3 .

The direct potential mechanisms have been studied by local and international researchers in order to protect biodiversity of tourism destinations and its surrounding areas (i.e., Kinnaird and O'Brien 1996, Kasmidi et al. 1999, Walker et al. 2000, de Vantier and Turak 2004, Kusen and Tioho 2009, Paulsen 2009). Increased tourist demand to resources will stimulate systemic exploitation of NSP's biodiversity. Growth of tourist accommodation will tend to extraction of timber and non-wood forest products (i.e. bamboo and rattan) in order to meet the civil construction needs. Illegal collection of coral reefs as souvenirs has been reported widely in many coastal tourism destinations in the world, particularly in NSP.

Indirect potential mechanism of tourism to Biodiversity has received less attention in NSP. Principally, the impacts of global tourism growth are many. An invasion of tourists into a fragile area will potentially alter ecosystem's integrity, structure and composition. An increase of tourist number can potentially stimulate uncontrolled rapid development, pollution, and wild habitat degradation. Scholars point out those tourists as outsiders are able to make changes to local social organization and behavior, and systematically lead to indigenous system extinction (Walker et al. 2000, Roe et al. 2003, Weaver 2005).

There is a growing concern in tourism regarding the increasing severity of coastal degradation in tourism development. The required of land for marinas, hotels and tourism complex facilities were the causes of deforestation in coastal areas. Such conversion has increased the pressure on the remaining coastal forest. Kasmidi et al. (1999) reported regarding the huge coral and mangroves tree exploitation in 1972 to establish trans-Sulawesi Highway. Tourism accommodations significantly became harbors of non-native species. In NSP, there are numerous introduced plants species found in hotel's parks and gardens such as Lantana camara, Bougainvillea spectabilis,

Table 3. The type of potential mechanisms of tourism impacts on biodiversity in North Sulawesi Province

\begin{tabular}{ll}
\hline Direct potential mechanisms & Indirect potential mechanisms \\
\hline $\begin{array}{l}\text { Exploitation of biodiversity for } \\
\text { food from forest and coastal } \\
\text { ecosystems }\end{array}$ & Local people social organization \\
$\begin{array}{l}\text { Extraction of timber and non- } \\
\text { wood forest products for hotel } \\
\text { and lodge material }\end{array}$ & Global tourism growth \\
$\begin{array}{l}\text { Collection of wildlife as } \\
\text { souvenirs }\end{array}$ & Social and economic gaps \\
$\begin{array}{l}\text { Expansion of aquaculture in } \\
\text { coastal areas }\end{array}$ & Poor tourism policy and \\
Extraction of corals for & regulation \\
infrastructure development & Absent tourist code of conduct \\
\hline
\end{tabular}




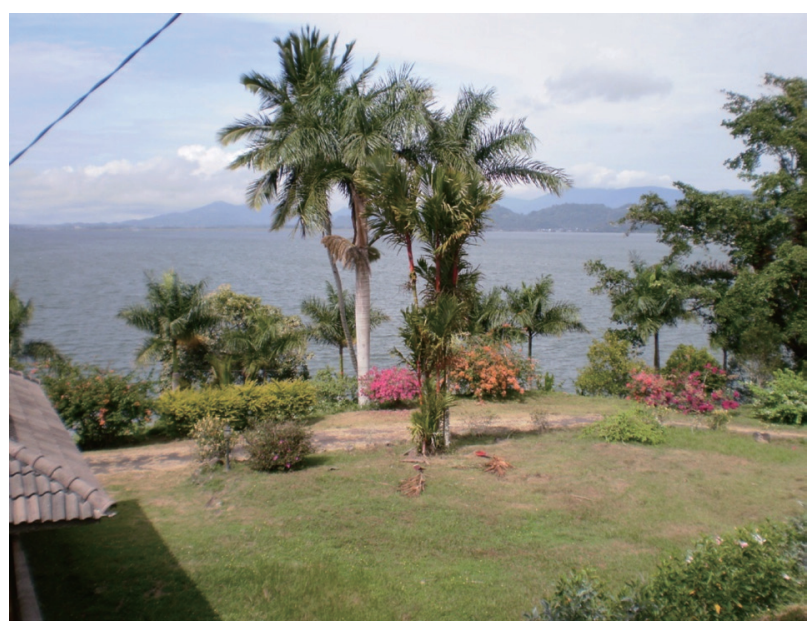

Fig. 2. Exotic species (Bougainvillea, palm, etc.) as ornamental plants in a tourist lodge.

Roystonea regia, Duranta erecta, and Pachystachys lutea (Fig. 2).

Lack of adequate biodiversity management in tourism destination areas has been recognized as a serious problem in recent years in NSP. The major point of the problems, however, was the abundance of visitors in conservation areas. A recent study by de Vantier and Turak (2004) in Bunaken suggested that diving in coral reefs has destroyed coral reefs significantly. Bunaken was visited by numerous visitors and experienced coral reef disturbance. Nowadays, the most suffered corals are branching and foliose growth-form corals such as Porites cylindrica, Porites nigrescens, Montipora aequituberculata, Mycedium mancaoi and Galaxea horrescens. In order to maintain coral reef diversity, projects related to ecosystem rehabilitation and designing carrying capacity were implemented to enhance sustainable tourism in Bunaken.

The negative effects of tourism on the wildlife biology and ecology have been described by Reynolds and Braithwaite (2001). In NSP, Kinnaird and O’Brien (1996) reported that tourist activities may have changed primates' behaviors. Observations by Paulsen (2009) in Macaca nigra (Black macaques) population at the Tangkoko Nature Reserve showed behavioral and physiological differences between the groups that had the most vs. least exposure to tourists. The study found that hormone concentration was the highest in the group with the most exposure to humans. The impact of tourism on the wildlife in NSP may have been less reported, but it is in fact widely apparent. There are few studies on tourism planning and development done from the perspectives of wildlife ecology. Moreover, the document of tourism planning seems to less accommodate for wildlife conservation as a component of tourism of natural attraction. According to Reynolds and Braithwaite (2001), the impacts of tourism to wildlife are now widely recognized. Tourist disturbance to wildlife habitat has been altering species behaviors, population structure and viability. In NSP, minimizing wildlife disturbance due to tourism activities will require major changes in existing tourism planning and development.

\section{Challenges to sustainable tourism in North Sulawesi}

These days, sustainable tourism has become a crucial issue in the tourism industry. According to World Tourism Organization, World Travel and Tourism Environment Research Center, Earth Council (1996), sustainable tourism is characterized by an optimal use of resources in a sustainable manner and with respect to socio-cultural authenticity of local people. Moreover, sustainable tourism should be able to provide socio-economic benefits to all stakeholders. Sustainable tourism emphasizes an open and wide participation of all stakeholders. Scholars argue that sustainable tourism will become the key to enhance economic growth and biodiversity conservation as well as community development in many developing countries (Gunn and Var 2002, Drumm and Moore 2005, Weaver 2005). Therefore, it is crucial that tourism planner understand the environmental, socio-political and economical aspects. Such understanding provides opportunities to develop more efficient and effective actions. Principally, it should be understood that the idea of biodiversity conservation cannot be separated from any tourism planning or development.

In the next few decades, tourism is likely to play an important role in North Sulawesi. The main challenge for sustainable tourism, however, is reduction of overall factors which can lead to biodiversity disturbance. In the perspectives of landscape ecology, the most important point in selecting a new tourism destination system is the anticipation of biodiversity destruction. According to Hong et al. (2007), landscape ecology has been widely acknowledged as an important approach in spatial planning, including tourism issues. Consequently, mapping biodiversity, both spatial and temporal, is a crucial step in every sustainable development scenarios. In NSP, however, such integrative schema to plan land uses based on biodiversity content is absent and should be overcome. It is particularly relevant in the recent trend since the statistical data clearly indicate the power of biodiversity in tourism industry. 
High level of biodiversity has several implications for tourism development in NSP. Sustainability requires biodiversity conservation and resources management. Diversified destination products that include tourism events are also required. Biodiversity is necessary not only for the development of tourism attractions, but also for the consumption needs of tourists. Linking biodiversity, economy and social concepts are crucial for tourism destination planning and development (Gunn and Var 2002, Hakim et al. 2009). In such a case, however, the information on the recent biodiversity levels in North Sulawesi is limited due to the lack of comprehensive survey efforts. This limitation should be solved systematically. Effective tourism management can only be successful if it is based on the comprehensive information of the biodiversity status of the target area. In terms of tourism destination management, it is important to know the species diversity and its population structure in and around the destination site.

Another issue that requires attention is the control of tourist number and activities. Every year, more than 9,000 visitors enter Bunaken and its adjacent waters. There is a positive correlation between diver activity and coral reef disturbance in Bunaken as well as between tourist contact intensity and primate's behavior and physiology in Tangkoko Nature Reserve (de Vantier and Turak 2004, Kusen and Tioho 2009, Paulsen 2009). Therefore, managing tourists seems to be the best policy towards sustainable destination in NSP.

Local people's role in tourism planning and decision making is less obvious in NSP. Design for tourism planning and implementation in NSP therefore should involve the local community. According to Gunn and Var (2002), sustainable tourism should stress the importance of conservation of biodiversity and participation of the local people. Recognition of local people in tourism planning and implementation is evident in many regions in the world. For instance, harmonious indigenous landscapes which are used as tourism attractions are often results of traditional management which is closely allied in the life of local people. Since biodiversity is closely linked with local people and tourism, it provides opportunities to enhance NSP as an authentic, competitive and sustainable tourism destination. Therefore, local people of NSP should be encouraged and trained to take advantages of tourism.

The vulnerability of sustainable tourism in NSP is also related to the different perspectives among stakeholders. Conservationist, community, local government and tourism stakeholders typically have different views and perspectives of biodiversity conservation and sustainable tourism planning. Perspectives depend on the interest of each group. This situation can lead to conflicts among stakeholders. Therefore, the process by which regional tourism planning and development are drawn should involve the stakeholders.

\section{Conclusion and recommendation}

Sustainable tourism deals with the integration of environmental, economic and socio-cultural aspects. The schema for sustainable tourism in NSP can be conceptualized in Fig. 3. It is emphasized that the provision of biodiversity conservation is the most vital element and a prerequisite for tourism success. Any nature-based tourism implementation in NSP largely depends on the availability and quality of biodiversity. In the absence of any biodiversity conservation program, tourism will contribute to chemical and biological pollution, habitat degradation and resources exploitation. No tourism project is likely to be sustainable unless it involves proper biodiversity conservation scenarios. In order to meet such needs, NSP should implement several strategic issues, namely mapping biodiversity, designing areas to accommodate biodiversity conservation, and protecting fragile seascape-landscape. Applications of landscape ecology would provide excellent work.

Developing and increasing small-medium entrepreneurship (SME) has become significant in order to enhance local economic aspects. SME will allow and stimulate local entrepreneurs and enterprises to grow. Importantly, SME will be able to reduce unemployment, poverty and extensive uses of resources. Doing business differently means reducing stress to particular resources. Such economic schema will increase direct purchases from the local farmer and therefore will help farmer to develop their products. This schema will allow local people to receive economic benefits from tourism. Principally, however, environmental business should be implemented with the objectives to ensure tourism products and services meet environmental standards and consensus. For this reason, diversification of tourism products and services in NSP will become the key point of SME.

Achieving the well-being of local community is essential in sustainable tourism which can be attained by education and training programs. Such activities support public participation and will therefore accelerate tourism to achieve its sustainability goals. Codes of tourism practices are essential to protecting indigenous systems and for the socio-cultural carrying capacity. 


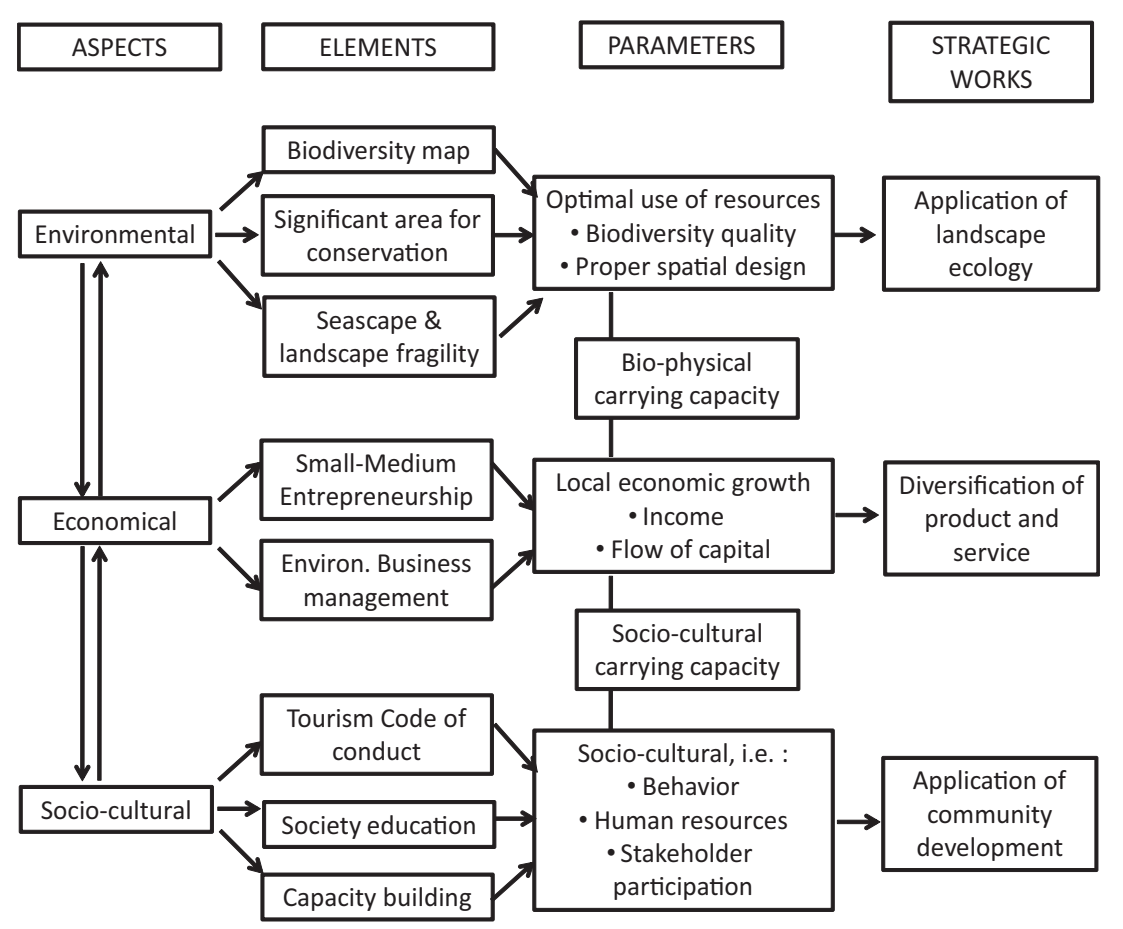

Fig. 3. Conceptual works towards sustainable tourism development in North Sulawesi Province.

Making comprehensive nature-based tourism planning requires an understanding of the biodiversity contents and relationship among its components. It is particularly important since some of the complexity of tourism destination in tropical ecosystems arises from the variety of biodiversity components. If the area is disrupted by reducing and changing the biological integrity, it may take a long time to return. Threats to biodiversity hot spots in NSP may come from tourism developers, local governments, tourist and community. Collaboration between local people and tourism developers, however, should be improved. Recent technology using spatial planning as a basis in decision making can be one of the integrative approaches to protect biodiversity from tourism development pressure. Hence, areas that contain valuable biodiversity but are involved in tourism planning and development should be given consideration. The protection of the hot spot biodiversity sites requires a number of laws and policies. In NSP, to be sustainable, the tourism planning and development must be integrative and systematic.

\section{ACKNOWLEDGMENTS}

The authors are thankful to Sigfed Berhimpon, Adrian Pangemanan, Rudy Wenas and Diane Pioh for their dis- cussion. Our thanks are extended to Bagyo Yanuwiadi, Regina Butar-butar and Olga Pradana for their data and information contribution in the field. Our thanks are due to National Research Foundation of Korea Grant funded by the Korean Government (NRF-2009-361-A00007).

\section{LITERATURE CITED}

Badan Perencanaan Pembangunan Nasional (BAPPENAS). 2003. Indonesian Biodiversity Strategy and Action Plan 2003-2020. National Development Planning Agency, Jakarta.

BPS Sulut. 2009. Sulawesi Utara dalam Angka 2009 (North Sulawesi Statistics, 2009). Badan Pusat Statistik Provinsi Sulawesi Utara, Manado.

Cunningham WP, Cunningham MA, Saigo BW. 2003. Environmental Science: A Global Concern. 7th ed. McGraw Hill, Boston, MA.

Damanik J, Kusworo HA, Raharjana DT. 2005. Poverty Alleviation throughout Tourism. Keppel Press, Yogyakarta.

de Vantier L, Turak E. 2004. Managing Marine Tourism in Bunaken National Park and Adjacent Waters, North Sulawesi, Indonesia. Project Report of Natural Resources Management III \& Program's Areas \& Agriculture Team, Jakarta. 
Dishut Sulut. 2008. Statistik Dinas Kehutanan Provinsi Sulawesi Utara Tahun 2008. Dinas Kehutanan Sulawesi Utara, Manado.

Drumm A, Moore A. 2005. Ecotourism Development: A Manual for Conservation Planners and Managers. The Nature Conservancy, Arlington, VA.

Erdmann MV, Caldwell RL, Jewett SL, Tjakrawidjaja A. 1999. The second recorded living Coelacanth from North Sulawesi. Environ Biol Fishes 54: 445-451.

Forest Watch Indonesia (FWI). 1996. Inventarisasi Hutan Nasional. Forest Watch Indonesia, Jakarta.

Fox J, Wasson M, Applegate G. 2000. Forest Use Policies and Strategies in Indonesia: A Need for Change. Word Bank Working Paper, Jakarta.

Government of Indonesia. 2008. Indonesia Law No. 26 Year 2008, March 10, 2008. Government of Indonesia, Jakarta.

Gunn CA, Var T. 2002. Tourism Planning: Basics, Concepts and Cases. Routledge, New York.

Hakim L. 2011. Cultural landscapes of the Tengger Highland, East Java. In: Landscape Ecology in Asian Cultures (Hong SK, Wu J, Kim JE, Nakagoshi N, eds). Springer, Tokyo, pp 69-82.

Hakim L, Hong SK, Kim JE, Nakagoshi N. 2008. Tourism and cultural landscape at Tengger, East Java: the implications for ecotourism planning. Korean J Environ Ecol 22: 207-220.

Hakim L, Kim JE, Hong SK. 2009. Cultural landscape and ecotourism in Bali Island, Indonesia. J Ecol Field Biol 32: 1-8.

Hakim L, Nakagoshi N. 2008. Planning for nature-based tourism in East Java: recent status of biodiversity, conservation, and its implication for sustainable tourism. Asean J Hosp Tour 7: 155-167.

Holmes D. 1996. The Birds of Sulawesi. Oxford University Press, Kuala Lumpur.

Hong SK. 2011. Eco-cultural diversity in island and coastal landscape: conservation and development. In: Landscape Ecology in Asian Cultures (Hong SK, Wu J, Kim JE, Nakagoshi N, eds). Springer, Tokyo, pp 11-28.

Hong SK, Nakagoshi N, Fu BJ, Morimoto Y. 2007. Landscape ecological applications in man-influenced areas linking man and nature systems: editorial introduction. In: Landscape Ecological Applications in Man-influenced Areas Linking Man and Nature Systems (Hong SK, Nakagoshi N, Fu B, Morimoto Y, eds). Springer Verlag, Dordrecht, pp 1-6.

Kartodihardjo H, Supriono A. 2000. The Impact of Sectoral Development in Natural Forest Conversion and Degradation: The Case of Timber and Tree Crop Plantations in Indonesia. Occasional Paper No 6(E). Center for In- ternational Foresty Research, Jakarta.

Kasmidi M, Ratu A, Armada E, Mintahari J, Maliasar I, Yanis D, Lumolos F, Mangampe N, Kapena P, Mongkol M. 1999. Rencana Pengelolaan Daerah Perlindungan Laut dan pembangunan Sumberdaya Wilayah Pesisir Desa Blangko, Minahasa Sulawesi Utara. University of Rhode Island, Coastal Resources Centre, Narragansett, Rhode Island, USA dan Bappeda Kabupaten Minahasa, Sulawesi Utara, Manado.

Kinnaird MF. 1997. Sulawesi Utara: Sebuah Panduan Sejarah Alam. Yayasan Pengembangan Wallacea, Jakarta.

Kinnaird MF, O'Brien TG. 1996. Ecotourism in the Tangkoko DuaSudara Nature Reserve: opening Pandora's box? Oryx 30: 65-73.

Koch A, Arida E, Riyanto A, Böhme W. 2009. Islands between the realms: a revised checklist of the Herpetofauna of the Talaud Archipelago, Indonesia, with a discussion about its biogeographic affinities. Bonn Zool Beitr 56: 107-129.

Kumar P. 2010. The Economics of Ecosystems and Biodiversity: Ecological and Economic Foundations (TEEB: The Economics of Ecosystems and Biodiversity). Earthscan Publications Ltd., Oxford.

Kusen JD, Tioho H. 2009. The present status of coral reef condition in Bunaken National Park and Manado Bay, North Sulawesi, Indonesia. Galaxea J Coral Reef Stud 11: 219-222.

Naumann CM. 2001. Biodiversity: Is there a second chance? In: Biodiversity: A Challenge for Development Research and Policy (Barthlott W, Winger M, eds). Springer Verlag, Berlin, pp 3-11.

Pangemanan PLL, Luntungan J, Waworuntuk J, Pangkey H. 2002. Profil Pariwisata Pesisir Kabupaten Minahasa, Kota Manado dan Kota Bitung. University of Rhode Island, Coastal Resources Centre, Narragansett, Rhode Island; Bappeda Kabupaten Minahasa, Sulawesi Utara, Manado.

Paulsen DI. 2009. The behavioral and physiological effects of ecotourism on the Sulawesi Black Macaques at the Tangkoko Nature Reserve, North Sulawesi, Indonesia. PhD Dissertation. University of Washington, Seattle, WA.

Putri DMS, Kurniawan A, Siregar M, Arinasa IBK. 2006. Koleksi Pohon Sulawesi Kebun Raya Bali. Lembaga Ilmu Pengetahuan Indonesia, Kebun Raya Eka Karya Bali, Singaraja.

Ramadhanil R, Gradstein SR. 2004. Herbarium Celebense (CEB) dan peranannya dalam menunjang penelitian taksonomi tumbuhan di Sulawesi. Biodiversitas 5: 36-41. Rasmussen PC. 1999. A new species of Hawk-Owl Ninox from 
North Sulawesi, Indonesia. Wilson Bull 111: 457-464.

Reynolds PC, Braithwaite D. 2001. Towards a conceptual framework for wildlife tourism. Tour Manage 22: 31-42.

Rhee S, Kitchener D, Brown T, Merrill R, Dilts R, Tighe S. 2004. Report on Biodiversity and Tropical Forests in Indonesia. US Agency for International Development, Jakarta.

Roe D, Harris C, de Andrade J. 2003. Addressing Poverty Issues in Tourism Standards. Pro Poor Tourism Working Paper No. 14. ODI-IIED-CRT-The Russell Press, Nottingham.

Ross S, Wall G. 1999. Evaluating ecotourism: the case of North Sulawesi, Indonesia. The impact of regionalization. Tour Manage 20: 673-682.

Shekellee M, Groves C, Merker S, Supriatna J. 2008. Tarsius tumpara: a new tarsier species from Siau Island, North Sulawesi. Primates Conserv (23): 55-64.

Sittadewi EH. 2008. Fungsi strategis Danau Tondano, Perubahan ekosistem dan masalah yang terjadi. J Teknol Lingkung 9: 59-66.
Teguh H, Manoppo R, Siwu S. 2001. Mengenal Beberapa satwa Sulawesi Utara dan Gorontalo (Wildlife of North Sulawesi and Gorontalo).Wildlife Conservation SocietyIndonesia Program, Sulawesi, Manado.

Walker JL, Mitchell B, Wismer S. 2000. Impacts during project anticipation in Molas, Indonesia: implications for social impact assessment. Environ Impact Assess Rev 20: 513-535.

Wallace AR. 2000. The Malay Archipelago. Periplus, Singapore.

Weaver D. 2005. Sustainable Tourism. Butterworth-Heinemann, Oxford.

Whitten T, Mustafa M, Henderson GS. 1987. The Ecology of Sulawesi. Periplus, Singapore.

World Tourism Organization, World Travel and Tourism Environment Research Center, Earth Council. 1996. Agenda 21 for travel and Tourism Industry: Towards Environmentally Sustainable Development. World Tourism Organization, Madrid. 